University of Nebraska - Lincoln

DigitalCommons@University of Nebraska - Lincoln

Faculty Publications: Department of Teaching, Department of Teaching, Learning and Teacher Learning and Teacher Education

Education

September 2006

\title{
Pensando en Cynthia y su Hermana: Educational Implications of United States-Mexico Transnationalism for Children
}

\author{
Edmund T. Hamann \\ University of Nebraska - Lincoln, ehamann2@unl.edu \\ Victor Zuniga \\ División de Educación y Humanidades, Universidad de Monterrey \\ Juan Sanchez Garcia \\ Universidad Autónoma de Nuevo León
}

Follow this and additional works at: https://digitalcommons.unl.edu/teachlearnfacpub

Part of the Teacher Education and Professional Development Commons

\begin{abstract}
Hamann, Edmund T.; Zuniga, Victor; and Sanchez Garcia, Juan, "Pensando en Cynthia y su Hermana: Educational Implications of United States-Mexico Transnationalism for Children" (2006). Faculty Publications: Department of Teaching, Learning and Teacher Education. 60.

https://digitalcommons.unl.edu/teachlearnfacpub/60
\end{abstract}

This Article is brought to you for free and open access by the Department of Teaching, Learning and Teacher Education at DigitalCommons@University of Nebraska - Lincoln. It has been accepted for inclusion in Faculty Publications: Department of Teaching, Learning and Teacher Education by an authorized administrator of DigitalCommons@University of Nebraska - Lincoln. 


\title{
Pensando en Cynthia y su Hermana: Educational Implications of United States-Mexico Transnationalism for Children
}

\author{
Edmund T. Hamann \\ Department of Teaching, Learning, and Teacher Education \\ University of Nebraska \\ Víctor Zúñiga \\ División de Educación y Humanidades \\ Universidad de Monterrey \\ Juan Sánchez García \\ Instituto de Investigaciones Sociales \\ Universidad Autónoma de Nuevo León
}

\begin{abstract}
We use 3 brief educational biographies of students in Mexico who have previously attended public school in the United States to introduce this literature review on United States-Mexico transnational students. This article is also the first of several planned articles stemming from a currently ongoing, Consejo Nacional de Ciencia y Tecnologia-supported research study. As such, the purpose here is to highlight some of the dynamics faced by students who need to negotiate 2 educational systems (the United States and Mexico) and who fit neither a classic United States immigrant typology nor the typical premises around which schooling in Mexico is organized.
\end{abstract}

Key words: U.S. schooling, Mexican schooling, migration, transnationalism, mobility, sojourner student

Correspondence should be addressed to Edmund T. Hamann, Department of Teaching, Learning, and Teacher Education, University of Nebraska-Lincoln, 118 Henzlik Hall, Lincoln, NE 68588-0355.

E-mail: ehamann2@unl.edu 
As the contradictory forces unleashed by economic globalization continue to tug and pull against the traditional structures that have in the past given citizenship and national affiliation meaning, it may well be that the most logical decision for transmigrants and even permanent immigrants is one that actively ... disavows allegiance to a single national entity.

—David Gutierrez (1999, p. 327)

\section{CYNTHIA, HER SISTER, AND ROSA}

Mexico's National Immigration Institute just announced that 22,055 children under the age of 18 were deported to Mexico in 2005, a $63 \%$ increase over the 13,000+ minor deportees in 2004 (Dellios, 2006). The newspaper Education Week just published a three-page in-depth report on a few California districts hiring tutors in Mexico to work with migrant students who pass most of the year in the United States, but spend a month or more in Mexico around the Christmas holidays (Lutton, 2006). There is no claim here that most students in Mexico with U.S. school experience are deportees; nor is there a claim that most are binational and move regularly, legally, and reasonably predictably between the two countries; nor is there a claim that any third type of transnational is most prevalent. The literature review presented here does not comment on proportionality. But we note the government report and the newspaper story nonetheless to highlight that transnationalism of minors is an increasingly salient issue in the United States and Mexico and that possible old conceits conceptualizing movement as unidirectional (from Mexico to the United States) are misplaced.

This is a literature review concerning education and transnationalism, particularly as that topic pertains to students whose school trajectories have included both the United States and Mexico. It uses the vignettes that follow (actually just edited field notes) for illustrative purposes and introductory ones. The stories of Cynthia, her sister, and Rosa come from a research study, now underway, that involves all three of this article's authors (plus several others). That larger study will entail site visits to more than 300 schools in the Mexican states of Nuevo León and Zacatecas, the administration of surveys to more than 20,000 students, and interviews with more than 100 students currently in Mexican schools who have previously attended school in the United States. But there are only two findings from that inquiry so far that we want to share here. Per our analysis of data from the completed Nuevo León fieldwork (where school visits and surveys were carried out in the autumn of 2004), 2.1\% of students enrolled in Grades 4 to 9 in that state have previous experience in U.S. schools, suggesting that Nuevo León schools host approximately 10,000 such students. The students profiled below-Cynthia, her sister, and Rosa - are three of them. Our second finding is that they are not atypical. 
(October 2004-Nuevo León, Mexico) It is all more than a little incongruous for Cynthia. Today began like any other school day for her and her sister, or at least like any other school day since she and her sister had begun attending this primaria (elementary school) in rural Nuevo León Mexico two years earlier. Before that, both Cynthia and her sister had attended an elementary school in Oklahoma. But now, with her teacher's permission, Cynthia has been pulled out of class and is talking to us in her school's meeting room teacher's lounge. She is code-switching back-and-forth between Spanish and English as she compares her Mexican and U.S. school experiences with me, a gringo educational anthropologist from Rhode Island, and my colleague, a doctoral student at the Universidad Autonoma de Nuevo León. We have not solicited any answers in English. Indeed my colleague who is leading the interview is more comfortable in Spanish, but Cynthia calculates from my accented and flawed Spanish that she can switch to English. Of school in Tulsa she explains, "I always talk in English over there."

When I ask her if there is anyone here that she can speak to in English. She first says "no," but then brightens, "My sister knows English, too." She adds that she and her sister still speak English to each other, then offers "The principal said that my [her]mana is not going to pass and then she stay in third grade." With a little further clarifying, we discover that Cynthia's sister had to repeat third grade here in Mexico because, as Cynthia understands it, in her first year in Mexico her sister's Spanish was not good enough to keep moving up. Cynthia on the other hand transitioned without delay from fourth grade in Oklahoma to fifth grade here.

Next year Cynthia will begin secundaria (Grades 7-9) at a different school in a nearby town. Although those are the oldest required grades of public education in Mexico, as a good and eager student (according to her self-characterization and her teacher's), Cynthia expects after secundaria to continue on to preparatoria (grades 10-12). She explains, "I want to study more."

When I ask, "What do you want to study? What things interest you?" She responds, "I want to be a teacher in English." I ask her to clarify where she would do this. She offers, "Maybe I'll go back to Tulsa."

I then ask if she has family who still live in Tulsa. She says she does. When I ask if she ever sees them, she says "No", but clarifies that they talk a lot on the telephone. I do not ask whether a lack of documentation keeps her from going back to Oklahoma or keeps her cousins from coming to Mexico to visit. Knowing that she was born in Mexico (and moved to Oklahoma at age two), it seems plausible that she cannot legally cross the border (though her U.S.-born younger sister can). Nor, I suspect, do her cousins in Oklahoma have documentation. That would explain Cynthia's negative an- 
swer regarding the prospects of their visiting Nuevo León. (From Hamann's field notes, October 2004)

(December 2004) I met a student today, Rosa, a 7th grader who has attended schools in Mexico only since Sept. 28. She agreed that Juan and I could interview here only if we did so in English (which meant I led the conversation, not Juan). She was born in San Luis Potosí but left for the U.S. at age 3. All the rest of her schooling (including 7 th grade last year) was in the U.S., in four different districts in Texas. Family problems explain the mobility, including why they have come back (her father broke a sufficiently major/minor law that he was deported rather than incarcerated, and his family followed). Family problems also explain why Rosa went to two weeks of fifth grade in Houston (while living with cousins). Rosa says she speaks English at home with her siblings, all of whom are younger. She says that her parents usually speak to her and her siblings in English as well, although they use Spanish with each other.

Here in Nuevo León, Rosa is failing all of her classes but English, art, and PE. On the other hand her English teacher seems to welcome her help. She has no friends in the school. She describes herself as shy. She's the only one in her secundaria who has been in school in the U.S. (although many have migrated from other Mexican states). She recounted that she had lost a number of her markers because classmates stole them. Art here requires bringing your own supplies. She claims to be worried about her ample supply of crayons now. (From Hamann's field notes, December 2004)

We do not know Cynthia or Rosa well, having spent but an hour with each of them. We do not directly know Cynthia's sister at all, although two of our colleagues during that school visit did meet her when they visited her fourth grade classroom to administer a questionnaire. We do not know the directors or teachers at Cynthia and her sister's school well, although we gladly conversed with several of them for about $2 \mathrm{hr}$ and we shared a small meal. We accept their characterizations in those conversations that their school had limited capacity to respond to a student who arrives with stronger skills in English than Spanish (as Cynthia's sister did). We accept their statement that, with the exception of one teacher in their school who has experience in the United States, none of them have had professional experience or training that would help them to better support transnational students. We accept their characterization that Cynthia is a strong student, perhaps the kind that thrives anywhere, while her sister seems to face more challenges.

We do not know the teachers at Rosa's school well either, although we interviewed one for almost an hour. He explained that the real challenge at Rosa's 
school were the social problems of the community it served. Many of Rosa's classmates are from nationally mobile families, from Puebla, Oaxaca, and Veracruz, and their economic security is fragile. In this kind of troubled environment, Rosa's unique profile as a transnational sojourner student is invisible, except to the English teacher who regards her as a sometime resource for pronunciation help.

Despite not knowing Cynthia, her sister, nor Rosa well, we offer sketches here for several reasons. They are empirical proof in Mexico of a phenomenon we have called "sojourner students" (Hamann, 2001). In 2001 we built a conjectural case to develop our definition, noting for example that in interviews conducted in Georgia with a Latino newcomer community by Hernández-León, Zúñiga, Shadduck, and Villarreal (2000) that a quarter of the surveyed adults expected that they and their families would not still be living in that community in 3 years time. We wondered if they left where they would go. In that 2001 article, we recalled a 13-year-old Latina girl Hamann had met in rural Kansas as part of his master's thesis research (Hamann, 1995), accompanying a Mexican-born paraprofessional on a home visit. The paraprofessional had tried to find out why that girl was truant, and the girl's father had explained that he had kept her home to help as an interpreter who could support his search for work. If he could not find work, the family would need to move, perhaps back to Mexico. The girl was displaceable, a sojourner.

But our emphasis here has changed a little from that noted in 2001. Our real cases of Cynthia, her sister, and Rosa are not about dislocation as a prospect, but about transnational dislocation as transpired fact. Cynthia, her sister, and Rosa offer a human face to what appears to be an increasingly common dynamic - students not following the expectation that predominates in the United States that students born outside the country are immigrant students. Given that they are back in Mexico (at least for now), Cynthia and Rosa were not immigrants. Immigration implies a permanency of relocation that, in turn, affects the calculus of what students need. The common praxis of schooling in the United States (and elsewhere) is undergirded by assimilationist and citizenship-developing presumptions (Cohen 2000; Commission on the Reorganization of Secondary Education, 1918; Conant, 1959; Durkheim, 1956; Hornberger, 2000; Levinson \& Holland, 1996; Olneck, 1995; Tyack, 1974) that poorly aligns with transnational sojourner students' life circumstance and worldview. For students permanently relocated to the United States, the school can be a key socializing agent, an agent of acculturation or even assimilation (Gibson, 1997) that prepares students for viable adulthoods in the United States. ${ }^{1}$ But Cynthia, her sister, and Rosa may not spend their adulthoods in the United States or in the United States only; already their biographies include a return (in Cynthia's and Rosa's cases) or an emigration (in Cynthia's sister's case) to Mexico. Maybe Cynthia, her sister, and Rosa need to be ready for an adulthood

\footnotetext{
${ }^{1}$ We are ignoring here, temporarily, the roles of power, identity, and social stratification. Each of these topics is important; they are brought up later.
} 
in the United States (which sets up the question of how aptly Mexican schools prepare youth for such trajectories), maybe they need to be ready for an adulthood in Mexico, but just as likely they need to be ready for an adulthood negotiating both. Setting aside their adulthoods for a moment, at this stage of their lives they need schools that can respond well to the fact that they have life and school experience somewhere else.

A final reason for focusing on Cynthia, her sister, and Rosa is to introduce a mixed-method study we have begun with the support of Consejo Nacional de Ciencia y Tecnologia, Mexico's national science foundation. The goals of that larger study are to tally the number of Mexican students in two Mexican states with experience in U.S. schools, to gain insights on how such students fare in Mexican schools, to learn about U.S. schooling through a population that U.S.-based studies could not easily access, and to consider phenomenologically how transnational sojourner students' view their education on both sides of the border. ${ }^{2}$ Because Cynthia, her sister, and Rosa each, so far, seem to be on different educational trajectories, sketching all three of them reminds us that the transnational sojourner student population is heterogeneous, a point consistent with, but not obvious from the literature review that forms the bulk of this article.

Describing Mexican students in Mexico who have school experience in the United States, Trueba asked both "How do children adjust in Mexico and back in Mexican schools? ... For those who return to Mexico for extended periods of time, what is the impact of the socioeconomic, political, and cultural changes they have experienced as they engage in daily life in Mexico?" (1999, p. 267). In a complementary vein, Mahler (1998, p. 84) has asked whether the children of transnationally mobile adults also become transnationally mobile. These are questions that inform this article and the larger investigation of which it is a part.

\section{WHY DID CYNTHIA, HER SISTER, AND ROSA MOVE? TRANSNATIONALISM FROM BELOW AND YOUTH}

In the last section we used the terms transnational and sojourner to characterize Cynthia, her sister, and Rosa. Webster's defines transnational as "extending or going beyond national boundaries." We take the term sojourner from Hackenberg's (1995, p. 248) referral to the sojourner versus settler debate that has been ongoing in international migration research circles for several decades (e.g., Chavez, 1988). That debate focuses on when/whether transnational newcomers to a receiving

\footnotetext{
${ }^{2}$ Although we are mainly referencing schooling with our use of the term education, our study does examine how transnational sojourner students regard each country and how they identify themselves in terms of ethnicity and nationality, so education can be understood as encompassing more than just school experience.
} 
community should be considered permanent members of their new community. By emphasizing the term sojourner we are not rejecting the settler argument (i.e., that many newcomers are settling as permanent members of their new locales; see González Baker, Bean, Latapi, \& Weintraub, 1999; Gutierrez, 1999; and Massey, Alarcón, Durand, \& Gonzákez, 1987). But we do assert that not all newcomers are permanent settlers. ${ }^{3}$ In Oklahoma, Cynthia and her sister were not permanent settlers. Likewise, Rosa was not a permanent newcomer to Texas.

A quick review of contemporary studies of transnationalism reveals why transnational sojourner students and the households they are part of are vulnerable to dislocation. The same review highlights the incompleteness and sometime inaccuracy of conceptualizing international migration strictly in terms of immigration and emigration-well after initially joining a migration flow, a persistent portion of international migrants, including some school-age migrants, seem still to be mobile, still to be binationally tied, and still not to be fully settled in their new environs. Sojourners' "life worlds are neither 'here' nor 'there' but at once both 'here' and 'there"" (Smith 1994, p. 17, italics original). This is partly because of the cultural and material conditions encountered in both sending and receiving communities. However, the emerging concept of "transnationalism from below" (Smith \& Guarnizo, 1998) also helps explain this transnational flux by reminding us of the agency and active decision making engaged in by the millions of families and individuals who cross (and often recross) international borders as, subject to constraints, they balance aspiration, need, risk, affiliation, responsibility, and awareness of self and circumstance. Massey and others have called this semipermanent transnationalism a "culture of migration" (cited in Brettell \& Hollifield, 2000, p. 16).

Transnational sojourner students and other members of their households fit within what Smith and Guarnizo (1998, p. 18) call "the new transnational working class," a class that engages in transnationalism from below. Transnationalism from below refers to the active decision making by members of economically vulnerable households to reduce their vulnerability by enacting strategies that take advantage of legal, economic, and cultural resources in more than one nation state. Transnationalism from below also indexes the advance of globalizing economic forces and the changes in communication, transportation, and legal technologies that together are contextual features that shape transnational migrants' choices and cosmologies.

As Appadurai (1996) noted, the current opportunity for immigrant newcomers to maintain links with their sending countries is unprecedented. One can think of the 1,000 plus Mexicans, noted by Ainslie (1999), who return to Tehuixtla (normally a village of 200) for the Christmas season and who send remittances there year round.

\footnotetext{
${ }^{3}$ We have modified the term "sojourner student" with the additional adjective "transnational" in several places. Technically, we are just being redundant when we do so, but it strikes us that it is sometimes a useful reminder.
} 
Appadurai (1996, p. 4) offers examples of Turkish "guest workers" in Germany watching Turkish films and Pakistani cab drivers in Chicago listening to cassettes of sermons recorded in mosques in Pakistan and Iran to assert that the contemporary explosion of mass media and the simultaneous acceleration of historic processes of transnational migration together have created new "diasporic public spheres." He adds that such deterritorialized public spheres confound theories that depend on the continued salience of the nation-state as the key arbiter of important social changes. It does not seem to be too much of a stretch to apply Appadurai's description to what Limón (1998), borrowing from Paredes, calls "Greater Mexico" (i.e., the deterritorialized public sphere that includes all portions of North America where Mexican-origin people live). In Oklahoma, clearly Cynthia's parents maintained sufficient ties to Nuevo León that it was a viable region to move back to. In Rosa's case, it seems to be her father's status as Mexican-born, rather than U.S.-born that has her back in the country she left as a toddler.

Yet the Ainslie (1999) example and Mary Petron's (2003) study of Mexican teachers of English in Nuevo León who travel to Monterrey and other cities to get their "Kentucky Fried Chicken fix" also remind us that transnationalism is not just immigrants maintaining ties with their countries of origin, but also returned migrants bringing back habits and customs acquired from their time in the extranjero. Now in Mexico, with their language maintenance activities and their telephone calls to cousins in Oklahoma, Cynthia and her sister are, even as minors, exercising agency to maintain ties to their previous community in the United States.

Acknowledging transnationalism from below's emphasis on agency reminds us that transnational students, or at least the adults in their household, choose to stay, to relocate, and/or to gather information about opportunities and survival strategies. ${ }^{4}$ In so doing, their families may challenge the social hierarchy. However, transnational students and their families exercise agency subject to the constraints of daily survival needs, structural impediments, and the partial access to information through which they understand their circumstances and options. From below makes a realistic statement about power, as those acting from below have less power than those acting on them from above. Those making choices from below confront more limited opportunity horizons and more pressing immediate needs. This makes long-term planning difficult and leaves children vulnerable to the challenges of dislocation.

Often, there are economic or partially economic explanations for transnational students' rootlessness or mobility. They and/or the households they are part of have been dislocated by the global spread of capitalism. For transnational sojourner students' parents, there are particular racialized dimensions to seeking work as a minority newcomer to a receiving community (Goldring, 1996, 1998; Tienda, 1989).

\footnotetext{
${ }^{4} \mathrm{Of}$ course deportations are not voluntary, but, even then, a previous exercise of agency is evident in the choice of risking living in a situation that could lead to deportation.
} 
Thus, displacement can remain a circumstantial reality for many as a long-term condition of global capitalism and not just in locations where global capitalism is newly penetrating, but also in the developed-world sites receiving newcomers. Adults in transnational student households (and sometimes the students themselves) have high labor force participation rates, but the jobs they have access to are almost always low status and vulnerable to changes in the economic cycle and/or enforcement of immigration laws.

Hackenberg and Kukulka (1995) documented both the limited duration of employment and the somewhat longer but not necessarily permanent stays in the region of newcomer laborers working in a Kansas meatpacking plants. In their case study, employers use a replacement labor strategy, offering minimal advancement opportunities and giving little weight to seniority. Workers seeking improved wages, work conditions, etc. are easily replaced with new employees. Cornelius (1989, p. 4) observed, "[Immigrant labor] can be brought on board quickly when needed in periods of peak product or service demand and disposed of just as easily when demand slackens." Spener wrote (1988, p. 138) "A primary role for immigrants in modern, post-industrial countries is to serve as a buffer between the domestic population, specifically the native-born working class, and the effects of periodic downturns in the economy." At the time Cynthia's parents left Oklahoma, there were a number of national news stories documenting how the stock-bubble-burst-related recession of 2002 had compelled some returned migration (e.g., Recio, 2002; Robertson, 2002).

Both Cornelius and Spener were describing manifestations of what dual system theorists call the secondary sector of the economy (Gutiérrez, 1999; Piore, 1979). Dual system theory posits that in the primary sector of the economy, jobs are salaried and stable, and an employee's educational status correlates with the rank and compensation of his or her job position. Because capitalist economies are cyclic, the primary sector has created an expendable, secondary sector that can be expanded in boom times and reduced during busts. Jobs in the secondary sector can be reasonably well paid, but offer little job security. Moreover, in the secondary sector an employee's school attainment does not correlate with his or her wage, job status, or job security. The secondary sector protects the primary sector from all but the sharpest economic fluctuations.

Households engaged in transnationalism from below thus need to buffer against the economic vulnerability of the secondary sector. Stark (1991) suggested risk-minimization is a main goal for extended families involved in transnational migration. The case studies of Ainslie (1999), Brittain (2002), Guerra (1998), Hagan (1994), and Valdés (1996) all show evidence consistent with this theory. Put simply, Stark suggested that because of the high vulnerability of economic niches available to transnationals (in their home country or as migrants) an extended family can reduce its vulnerability by spreading out. This strategy makes it more likely that some family members will be in temporarily prosperous enough circumstances (e.g., landing a job at a carpet mill in Georgia) to support other family 
members. The strategy depends on the continued salience of family or even fictive kin ties of those within the network (ensuring the intranetwork distribution of resources). Those in sending communities thus have an incentive to assure that those who have transnationally migrated maintain a connection to home. Perhaps such connections facilitated Cynthia's parents' return.

Massey et al. (1987, pp. 184-185) wrote: "Although temporary migration is numerically dominant, our understanding of migrant networks and the way they operate suggests that recurrent and settled migrations are crucial to supporting temporary migration and making it widespread." So the dynamic of some newcomers permanently settling supports a system where others are transient, or at least unsettled. The best answer to the settlement-sojourner debate may be "both," which means the presence of transnational students in Mexican schools is predictable.

\section{WHAT DO CYNTHIA, HER SISTER, AND ROSA BRING TO SCHOOL?}

Cynthia, her sister, and Rosa know school and community environments in two languages (though Rosa does not yet know Spanish as well as her school expects her to). They are bilingual, if not perfectly so, and biliterate to some degree. They demonstrate an ongoing interest in maintaining and developing skills in English and expect that at some point they will again be back in the United States. Although they have known a school environment much more elaborate and resource rich (in terms of material resources) than the one they currently attend, at least Cynthia seems favorably disposed to both this school environment and her previous one. Cynthia's favorable disposition to school and pride in her academic identity as "smart" are related orientations that her teachers can build on to assure her continued academic success. Having stayed back (because of the move to Mexico) Cynthia's sister's academic success seems a little less secure. And Rosa seems the most vulnerable of the three.

Anthropologists of education note that all students bring to school various "funds of knowledge"-knowledge acquired through their personal experience and family and cultural heritage (Gonzalez et al., 1995; Moll, Amanti, Neff, \& Gonzalez, 1992; Moll \& Gonzalez, 1997). These researchers (and others who have imitated them-e.g., Lee, 2004; Moje et al., 2004) have also noted that, from a constructivist orientation, efficacious schooling emphasizes recognizing and building from students' funds of knowledge. So they have developed teacher-training strategies to train educators to identify students' funds of knowledge and to adjust curricula accordingly. This second piece is crucial; educators not only need to know what their students bring to class, they also need to know how to respond to that knowledge and to have the discretion to do so.

Whereas an affirmative orientation toward skills and assets is important, it is not just assets that students like Cynthia, her sister, and Rosa bring to school. Although 
we do not know Cynthia or Rosa's immigration status when they lived in the United States, let's imagine for a moment that they or their parents were undocumented. Hagan (1994, p. 160) wrote:

The precarious and clandestine nature of undocumented life, with its constant ambiguity, discourages the migrant from making long-term plans. Thus decision making evolves into a continual process, whereby decisions shift with changing sets of opportunities, attitudes, and social relations in both the home and host community.

Hagan raises a crucial point about adults, which sets up questions regarding how and how well children can be insulated by their guardians (and by the assumptions of their schools) from the stresses referenced previously. This vulnerability and related tentative attachment to place pertains both to undocumented students and to documented students who live with undocumented parents/guardians. Although the Plyler v. Doe (1982) U.S. Supreme Court decision forbids schools being sites of immigration law enforcement, that does not protect minors away from school, nor their families. Moreover, this protection may be in jeopardy; in $1982 \mathrm{a}$ more liberal court approved it only 5-4.

As we have noted before (Hamann, 2001, 2003; Zúñiga, 2000; Zúñiga \& Hernández-León, 2005), members of the host community and newcomers in migration receiving sites construct and contest understandings of each other and their respective places in the community and larger society. From this negotiation, there are ideas extant in the public sphere and internalized by host and newcomer that mark some types of people as less belonging. Members of transnational sojourner households are often so marked and, in their risk minimization strategies of maintaining attachments elsewhere, they ironically contribute to this construction, although Cynthia and Rosa both reported that they enjoyed school in the United States. ${ }^{5}$

Thinking of citizenship not strictly in legalistic terms but rather as the right to full participation in the public sphere and full membership in the community (Joseph, 1999), transnational students can face resistance to their full claims of citizenship. We have applied this concept previously to U.S. receiving sites (Hamann, 2001), and Reyes (2000) and Serrano (1998) documented this for Puerto Rican students who return to the island.

This dynamic was clearly not in play in Cynthia's case. We grimaced (and subsequently changed the site visit protocol) when Cynthia's sixth grade teacher clarified to her class that they could rephrase our survey question about what they

\footnotetext{
${ }^{5}$ Our point here is not to construct the fault for the limited opportunities typically encountered/developed by transnational sojourner students on the backs of those same students. Rather we want both to note that the risk-minimization strategy embedded in transnationalism from below can impede opportunity maximization and to clarify that this is so because of the mismatch between the strategies rewarded by, in this case, the U.S. educational structure and the strategies required by a transnationalism from below.
} 
thought of students with U.S. school experience to: What do you think of Cynthia? Fortunately, her classmates consistently answered that they liked and welcomed her. Perhaps (and we offer this purely speculatively) they liked her because there was a dynamic in her community that viewed returned migrants and their relative wealth favorably (see Ainslie, 1999). However, Rosa seems to have been subject to skepticism and even harassment by her peers.

If transnational students are viewed as inauthentically Mexican and/or if they maintain claims to an American identity although in Mexico, the emergence of "nomadic" identity (Joseph, 1999) seems plausible. As Rosa's case and the research from Puerto Rico suggest, there are inhibiting factors at the non-U.S. community end that limit some transnationals' willingness to imagine themselves as fully part of their current environs (Anderson, 1991; Chavez, 1994; Guerra, 1998). ${ }^{6}$ They become students between two nations rather than of two nations.

\section{WHAT DO CYNTHIA, HER SISTER, AND ROSA NEED FROM SCHOOL?}

Appadurai's (1996) perspective on the declining salience of the nation state contrasts with that of Smith and Guarnizo $(1998$, p. 9) who pointed out that in studies of transnationalism "It is important to recall that the agents of 'receiving states' remain relevant actors." Presumably this point also holds for agents of 'receiving back' states. As Rippberger and Staudt (2002) illustrated strikingly in their comparative study of civics education in schools in El Paso and Ciudad Juarez, schools are state agents. They are consciously sites of national and civic identity construction. Thus emerges a central tension, the conflict between obviously state-tied entities (i.e., schools) and obviously transnational processes and phenomena. In this conflict, schools retain their power to convey or deny access and opportunity. So for transnational students like Cynthia, her sister, and Rosa, schools face a paradoxical task: to prepare students to negotiate well this national context and another one, with the latter not usually assumed to be part of their task.

So what can school teach to help students who are engaged in transnationalism from below? What kind of civics education do such students need? How should cumulative scope and sequence curricula be modified? What should school teach to those who need to negotiate multiple community environments (in two countries and at least two locales)? What can it teach to help students who will negotiate the "secondary sector" (Gutiérrez, 1999; Piore, 1979) or "bottom" (Spener, 1988) of the U.S. economy (and perhaps low-opportunity sectors of the Mexican econ-

\footnotetext{
${ }^{6}$ Here again we are not denying that many newcomers are permanently settling in the United States. Rather our focus is on those who are unable to settle or unsure that this would be the most risk-reducing and appealing choice.
} 
omy)? What should schools teach those who face the additional challenge of lacking legal work authorization or the right to go to college (Dyer, 1999)? How can a curriculum for transnational sojourner students be effectively delivered in face of such students' high mobility, their disjointed school experiences, and their tentative attachment to place? What literacies should schools help transnational students develop? To understand why literacies is a plural, consider Guerra's plural and context-dependent definition (1998, p. 58) of literacy:

[An] individual's literacies vary according to the personal and social circumstances of his or her life, so everyone is considered literate in certain situations and not in others. The goal, from this perspective, is not to master a particular form of literacy, but to develop one's ability to engage in a variety of social practices that require us to operate in a plethora of settings and genres to fulfill different needs and goals. In academic terms, it means that identifying and understanding a set of assumed universal standards is not only no longer possible, but no longer meaningful.

Lamphere (1992) and Goode, Schneider, and Blanc (1992) refer to schools as "mediating institutions" at which macrodynamics like transnational migration, economic stratification, and group boundary-marking processes (Barth, 1969) are enacted, contested, and endowed with various meanings at the individual and community levels. At U.S. schools, for transnational sojourner students that mediation is typically manifest as a hybrid of invisibility and dismissal (at least dismissal of that part tied to and needing to be ready for Mexico). Adrienne Rich (in Rosaldo, 1989 , p. ix) has written, "When someone with the authority of a teacher, say, describes the world and you are not in it, there is a moment of psychic disequilibrium, as if you looked in the mirror and saw nothing." By denying transnational sojourner students' very presence (by labeling them under other only partially descriptive categories-Latino/a, migrant, English language learner [ELL], limited English proficient [LEP])—and/or by dismissing their obligation to nonpermanent newcomers, schools put sojourner students at an academic disadvantage. The Educational Welcome of Latinos in the New South (Hamann, 2003) described how important the claims that "they are here permanently" were to those in a new U.S. receiving community who advocated for a substantive school response to Latino newcomers.

The converse question that can be poised but not answered from a consideration of just two sisters and another girl is whether transnational students are equally invisible in Mexico, with an important part of their experience and knowledge essentially unaccounted for in terms of school praxis with them. According to Reyes' (2000) study at two Puerto Rican high schools, being a returned migrant conferred a second class status as not quite fully Puerto Rican (a particular slap on the face for such students who had used a proud sense of Puerto Rican selfhood at school in the mainland in the face of challenges there that they were not quite American). 
Clearly such a lowered status dynamic seems possible in Mexico, perhaps it explains Rosa's treatment by her peers. But Rosa's case also illustrates invisibility. When we asked school administrators at her secundaria whether they enrolled any students with U.S. school experience, they answered that they did not think so (but, given the Nuevo León Secretary of Education's clearance, we were welcome to administer our survey in their classrooms).

There is a distinction between the substantial acculturative challenges encountered by immigrant students settling in a new community and the even more chaotic challenges encountered by students whose parents are transnational sojourners and who are not clearly rooted in either a sending or a receiving community. Such students embody Durkheim's (1956) notion of anomie even as they contest their rootlessness. Sojourner students face extra acculturative challenges; they need not only to learn how to negotiate this new place (i.e., the community surrounding their present school), but more fundamentally any new place, as the prospect looms that they will sooner or later be headed someplace else.

From a psychocultural perspective, Bruner observed, "Learning and thinking are always situated in a cultural setting and always dependent on cultural resources" (1996, p. 4). Transnational students need to know how to readily identify and access the cultural resources that support broadened (or viable) opportunity horizons in their new locale. They also need to retain and enhance their capacities and their facility with and access to cultural resources to negotiate the old places (i.e., the places they have previously lived and, given the data on circular and repeat migration, places where they may well live again). Their challenge is to develop metacognitive skills regarding negotiation of multiple places and multiple cultures. Yet concurrently, there is also the individual challenge of negotiating identity and group membership (Packer \& Goicoechea, 2000). To put the challenge bluntly, Cynthia's sister needed her Tulsa school to prepare her for school in Nuevo León, linguistically and across the content areas. Similarly, Rosa needed Texan schools (in several districts) to collectively ready her for sudden relocation to Nuevo León. But these needs were not recognized or anticipated, both Cynthia's sister and Rosa had to repeat a grade, a risk factor associated with dropping out.

Two main points relevant to transnational sojourner students should emerge from the discussion that follows: (a) noninclusive curricula can and do disadvantage transnational sojourner students and (b) creating curricula responsive to such students requires a rethinking of school organization, curriculum, pedagogy, student needs, and the relationships at the instructor/student/curriculum nexus. Perhaps a new binational educational policy needs to be articulated (Zúñiga, 2000). According to Freire (1970), students most readily learn ideas, facts, and perspectives that help them describe and negotiate their world. Heath (1983), Au and Jordan (1981), and others have found that nonmainstream students' school engagement and performance improved when the curriculum was adjusted in culturally familiar ways and included material about their communities and cultures. Thus, to 
the extent transnational sojourner students encounter in both the United States and Mexico a curriculum that captures neither their realities nor their goals, they are disadvantaged. Reyes (2000) noted that Puerto Rican teachers who were returned migrants provided the most advocacy and empathy for returned migrants. They were the ones who best attended to what Vygotsky called the students' "zones of proximal development" (Erickson, 1987).

Because of the disjointed nature of transnational students' schooling, it is particularly important that they gain learning-how-to-learn skills and also attention to the development of their selfhood and identity. But, if the cases of Cynthia, her sister, and Rosa are representative, there is no consciously developed expertise at the school to accommodate this need. Instead the response to struggles is with traditional instruments, like having Cynthia's sister and Rosa repeat a year because their schools were not ready for students better in English than Spanish.

It is not hard to envision many of the ways lack of legal status could be disruptive to a student's U.S. school experience in ways that later matter when such students have returned to Mexico (perhaps as deportees). Clearly a deportation is a directly traumatic event with expectable mental health consequences. (Whereas students will not be deported from school, workplace raids and neighborhood crime prevention activities can lead to students' deportation.) Writing about immigration into the United States, Suárez-Orozco and Suárez-Orozco (2001) noted at length how long separations from some caregivers, the tension of illicit border crossings, and the negotiation of the unfamiliar all can have psychological consequences for transnational children. How these stresses applied to Cynthia and her sister is unclear, but some manifestations of them seemed apparent in our encounter with Rosa.

Mahler's (1998), Hagan's (1994), Pugach's (1998), Valdés' (1996), Guerra's (1998), and Boehm's (2000) separate findings that obtaining legal status increased the binational mobility of members of the newcomer groups offers an intriguing different implication for what some students like Cynthia, her sister, and Rosa might need from Mexican schools. Noting again that Cynthia's sister was born in the United States and that she thus had legal access to the United States, it is not hard to imagine that according to the economic risk minimization strategy (Stark, 1991) of transnationalism from below that someday Cynthia's sister will be expected by her extended family to work in the United States and remit wages back. Rosa's U.S.-born younger siblings may face a similar task. By this scenario wouldn't it be helpful then if Cynthia's sister's Mexican school preparation improved the quality of U.S. economic niche for which she could ultimately aspire?

Wong Fillmore and Meyer (1992) found there often is an unarticulated conflict between two competing goals for language minority students- the goal of cultural assimilation versus the goal of cultural pluralism. Whereas transnational sojourner students, like Cynthia, her sister, and Rosa are not in quite the same category as language minority student, the parallel here holds. For them, the assimilationist or 
nationalist presumption that prevails in both U.S. and Mexican schools (Rippberger \& Staudt, 2002) is incomplete. Those on the assimilationist side may argue that not asking language minority students (and transnational students) to master the same rigorous content as other students is discriminatory. We are not arguing against this. Rather we are insisting that, as is, it is incompletely preparatory for transnational students.

Another curricular challenge in the education of sojourner students is to figure out not just a curriculum that builds on what such students already know, but one that is also conscious of the circumstances transnational students negotiate and likely will need to negotiate in the future. Using W. E. B. DuBois' famous term, Smith and Guarnizo (1998, p. 17) mention the "double-consciousness" required by and thus developed by transmigrants to negotiate the various domains they inhabit/traverse. Writing from a very different perspective, Parker, Ninomiya, and Cogan (1999) recently asked whether the time has come for multinational curriculum development. Perhaps such an effort would particularly benefit sojourner students. Though hardly the only point to focus on, a useful skill that could be consciously promoted by such a curriculum would be the capacity to "culture switch" (Clemens 1999, p. 116).

\section{ARE MEXICAN SCHOOLS READY FOR CYNTHIA, HER SISTER, AND ROSA?}

It is important to remember that Cynthia (but not her sister and not Rosa) apparently is thriving in her Nuevo León school, although whether that schooling can support her goal of someday teaching English is less certain. There are things that Mexican schools do that make schooling successful for some transnational students (or at least do not block students' success). Nonetheless, despite Cynthia's academic success, Mexican schools do not seem to be fully ready for students like her, her sister, and Rosa. They are not ready in several ways, some of which will be difficult to resolve. Jiménez recently wrote, "During a recent sabbatical in Mexico, I met with a returned migrant parent who spoke quite favorably concerning his children's experience in U.S. schools" (2004, p. 18). There are reasons for that parents' impression.

On one indicator-physical plant, or, more holistically, resources-Mexican schools are usually less well resourced than their U.S. counterparts (Rippberger \& Staudt, 2002). This does not intrinsically mean the quality of teaching or the rigor of the curriculum is also unequal. Indeed, in the preface to his book on his 10 years of ethnographic study of a Mexican secundaria, Bradley Levinson (2001, p. xv) noted that in several subject areas Mexican students at a given grade level seem to be tackling more rigorous curricula than their U.S. counterparts. Similarly, in her study Learning and Not Learning English, Valdés (2001) noted that the Mexican 
newcomer middle school students from nonrural sending communities in Mexico that she studied usually had more advanced math skills than what was on offer in the United States and thus that their first years of U.S. math were essentially lost time as concepts were covered that these students already knew. Yet a more rigorous curriculum in Mexico, when it happens, comes with its own hazards for transnational students, as students like Cynthia, her sister, and Rosa, coming to Mexico, may face material they are not ready for. Rosa and Cynthia's sister were held back.

The typical U.S. resource advantage does matter, however, in terms of pedagogy and impressions. Pedagogically, Mexican teachers cannot presume their students have access to the Internet, to word processing, and other technology-aided vehicles for study and communication, even in Nuevo León, which has been a national pioneer in promoting technology access in schools. Access to these aids in U.S. schools may be limited, but there are very few where students have no access at all. It follows then that transnational sojourner students' familiarity with these tools is not always readily built on in Mexico, particularly in primaria. (The Programa de Informática Educativa has, since 1994, endeavored to assure that all secundarias in Nuevo León have computers that student can access.)

The resource divide also matters in terms of impression. If Cynthia's school(s) in Tulsa and Rosa's in Texas were like the supposedly resource-poor urban elementary schools we are familiar with in other parts of the United States (i.e., in the Midwest, South, and the Northeast), they still had a lot more than did their Nuevo León schools. Apart from very speculative conjecture grounded in Cynthia's continued fondness for Oklahoma and Rosa's for Texas, we cannot say how, psychologically, they understood and made meaning from the resource gaps between U.S. and Mexican locations, but plausibly that gap could inform a student's assessment of how much and what kind of education was on offer in the new environment (Sizer \& Sizer, 1999). Teachers from Georgia visiting Mexican schools saw the resource scarcity there and wondered about how much education could be accomplished in such an environment (Hamann, 2003).

The issue of what Mexican schools need or need to do to be ready to best support Cynthia, her sister, and Rosa has its very tangible dimensions-in terms of resources, teacher training, linguistic accommodation, knowing better how to build on such students' life experience, etc. But there is an as important existential dimension around larger philosophical issues like what should schools be for that is a persistent different side of this whole consideration. Joseph noted, "citizenship is not organic but must be acquired through public and psychic participation" (1999, p. 3) and "notions of citizenship are infused with public images, official definitions, informal customary practice, nostalgic longings, accrued historical memory and material culture, comforting mythologies of reinvention, and lessons learned from past rejections" (1999, p. 5). Borrowing from Luykx (1999), schools are "citizen factories." So what kind of citizens and citizens of what are Cynthia, her sister, and Rosa supposed to become? 
We can pursue that question from nationalistic points of origin: What does Mexico want from its transnational sojourner students? What does the United States want to result from the school experiences of that portion of its population that moves back and forth between the United States and Mexico? But such questions beg the point of why identifying transnational sojourner student as an archetype matters, the nationalistic answers to this transnational and humanistic issue are intrinsically incomplete. Cynthia, her sister, and Rosa are not just Mexican, not just American; educational decision making processes that come from just one or the other of these perspectives then invariably is not fully responsive to who these girls are and can be.

Because transnational sojourner students are less accommodated at school than other populations, it follows that their bids for full citizenship can be undermined by the way citizenship is constructed at school in both countries. Returning to Smith and Guarnizo's (1998, p. 9) emphasis that studies of transnationalism need to consider the continued salience of agents of the receiving state (i.e., schools), we return to the inherent tension between transnationalism and the state, between the sojourner students and the school.

Spindler wrote, "In the anthropological view, schooling is cultural transmission. Schooling exists, in this view, to recruit new members into the community (usually its own offspring) and maintain the cultural system" (1982, p. 16). It follows that tending to the opportunities and needs presented by sojourner students is not easily consistent with the community defining and community sustaining roles performed by public schools. But if we are going to champion (or tolerate) a neoliberal globalizing economic order that generates transnationalism from below, then in our capacity as humans and educators (but not as members of nation states) we need to draw attention and action to the opportunities and needs presented by transnational sojourner students and to the ways that may require us to rethink notions of community and nation. Tenemos que pensar en Cynthia, su hermana, y Rosa.

\section{ACKNOWLEDGMENTS}

An earlier version of this article was prepared for the seminar: Educación $y$ Migración México-Estados Unidos: Retos y Perspectivas held at the Universidad de Monterrey in December 2004. We thank those who participated in that conference for their ideas and suggestions.

\section{REFERENCES}

Ainslie, R. C. (1999). Cultural mourning, immigration, and engagement: Vignettes from the Mexican experience. In M. Suárez-Orozco (Ed.), Crossings: Mexican immigration in interdisciplinary perspective (pp. 283-300). Cambridge, MA: Harvard University, David Rockefeller Center for Latin American Studies. 
Anderson, B. (1991). Imagined communities: Reflections on the origin and spread of nationalism (Rev. ed.). London: Verso.

Appadurai, A. (1996). Modernity at large: Cultural dimensions of globalization. Minneapolis: University of Minnesota Press.

Au, K. H., \& Jordan, C. (1981). Teaching reading to Hawaiian children: Finding a culturally appropriate solution. In H. Trueba, G. P. Guthrie, \& K. H. Au (Eds.), Culture in the bilingual classroom: Studies in classroom ethnography (pp. 139-152). Rowley, MA: Newbury House.

Barth, F. (1969). Introduction. In F. Barth (Ed.), Ethnic groups and boundaries: The social organization of cultural difference (pp. 9-38). Boston: Little, Brown.

Boehm, D. (2000). "From both sides" (Trans)nationality, citizenship, and belonging among Mexican immigrants to the United States. In E. Gozdziak \& D. Shandy (Eds.), Rethinking refuge and displacement, Selected papers on refugees and immigrants, 8 (pp. 111-141). Arlington, VA: American Anthropological Association.

Brettell, C. B., \& Hollifield, J. F. (2000). Migration theory: Talking across disciplines. New York: Routledge.

Brittain, C. (2002). Transnational messages: Experiences of Chinese and Mexican immigrants in American schools. New York: LFB Scholarly Publishing.

Bruner, J. S. (1996). The culture of education. Cambridge, MA: Harvard University Press.

Chavez, L. R. (1988). Sojourners and settlers: The case of Mexicans in the United States. Human Organization, 47, 95-108.

Chavez, L. R. (1994). The power of the imagined community: The settlement of undocumented Mexicans and Central Americans in the United States. American Anthropologist, 96(1), 52-73.

Clemens, E. S. (1999). From society to school and back again: Questions about learning in and for a world of complex organizations. In E. C. Lagemann \& L. S. Shulman (Eds.), Issues in education research: Problems and possibilities (pp. 105-120). San Francisco: Jossey-Bass.

Cohen, Y. A. (2000). The shaping of men's minds: Adaptations to imperatives of culture. In B. Levinson et al. (Eds.), Schooling the symbolic animal: Social and cultural dimensions of education (pp. 83-107). Lanham, MD: Rowman and Littlefield.

Commission on the Reorganization of Secondary Education. (1918). Cardinal principles of secondary education. Washington, DC: U.S. Bureau of Education, Bulletin No. 35.

Conant, J. B. (1959). The American high school today: A first report to interested citizens. New York: McGraw-Hill.

Cornelius, W. A. (1989). Mexican migration to the United States: Introduction. In W. A. Cornelius \& J. A. Bustamante (Eds.), Mexican migration to the United States: Origins, consequences, and policy options (pp. 1-21). San Diego: Center for U.S. Mexican Studies, University of California.

Dellios, H. (2006, February 12). Profile of immigrants changing. Chicago Tribune, 11.

Durkheim, E. (1956). Education and Sociology (S. D. Fox, Trans.). Glencoe, IL: Free Press.

Dyer, J. (1999, January 24). The dreams of Rigo Nunez. Atlanta Journal-Constitution, C1, C4.

Erickson, F. (1987). Transformation and school success: The politics and culture of educational achievement. Anthropology \& Education Quarterly, 18(4), 335-356.

Freire, P. (1970). Pedagogy of the oppressed. New York: Seabury.

Gibson, M. (1997). Complicating the immigrant/involuntary minority typology. Anthropology \& Education Quarterly, 28(3), 431-454.

Goldring, L. (1996). Blurring borders: Constructing transnational community in the process of Mexico-United States migration. Research in Community Sociology 6, 69-104.

Goldring, L. (1998). The power of status in transnational social fields. In M. P. Smith \& L. E. Guarnizo (Eds.), Transnationalism from below (pp. 165-195). New Brunswick, NJ: Transaction.

Gonzalez, N., Moll, L., Tenery, M., Rivera, A., Rendon, P., Gonzales, R., et al. (1995). Funds of knowledge for teaching in Latino households. Urban Education, 29(4), 443-470.

González Baker, S., Bean, F. D., Latapi, A. E., \& Weintraub, S. (1999). U.S. immigration policies and trends: The growing importance of migration from Mexico. In M. Suárez-Orozco (Ed.), Crossings: 
Mexican immigration in interdisciplinary perspective (pp. 81-105). Cambridge: Harvard University, David Rockefeller Center for Latin American Studies.

Goode, J. G., Schneider, J. A., \& Blanc, S. (1992). Transcending boundaries and closing ranks: How schools shape interrelations. In L. Lamphere (Ed.), Structuring diversity: Ethnographic perspectives on the new immigration (pp. 173-213). Chicago: University of Chicago Press.

Guerra, J. C. (1998). Close to home: Oral and literate practices in a transnational Mexicano community. New York: Teachers College Press.

Gutiérrez, D. G. (1999). Ethnic Mexicans and the transformation of "American" social space: Reflections on recent history. In M. Suárez-Orozco (Ed.), Crossings: Mexican immigration in interdisciplinary perspective (pp. 309-335). Cambridge, MA: Harvard University, David Rockefeller Center for Latin American Studies.

Hackenberg, R. A. (1995). Joe Hill died for your sins. In D. Stull, M. J. Broadway, \& D. Griffith, (Eds.), Any way you cut it: Meat-Processing and small-town America (pp. 232-264). Lawrence: University Press of Kansas.

Hackenberg, R. A., \& Kukulka, G. (1995). Industries, immigrants, and illness in the New Midwest. In D. Stull, M. J. Broadway, \& D. Griffith (Eds.), Any way you cut it: Meat-Processing and small-town America (pp. 187-211). Lawrence: University Press of Kansas.

Hagan, J. M. (1994). Deciding to be legal: A Maya community in Houston. Philadelphia: Temple University Press.

Hamann, E. T. (1995). Creating bicultural identities; The role of school-based bilingual paraprofessionals in contemporary immigrant accommodation (Two Kansas case studies). Unpublished master's thesis, University of Kansas, Lawrence.

Hamann, E. T. (2001). Theorizing the sojourner student (with a sketch of appropriate school responsiveness). In M. Carol Hopkins \& N. Wellmeier (Eds.), Negotiating transnationalism: Selected papers on refugees and immigrants, Vol. IX (pp. 32-71). Arlington, VA: American Anthropology Association.

Hamann, E. T. (2003). The educational welcome of Latinos in the New South. Westport, CT: Praeger.

Heath, S. B. (1983) Ways with words: Language, life, and work in communities and classrooms. Cambridge: Cambridge University Press.

Hernández-León, R.,Zúñiga, V., Shadduck, J.L., \& Villarreal, M. O. (2000). Needs assessment of the Hispanic community in Dalton. Unpublished manuscript, Universidad de Monterrey/The Georgia Project.

Hornberger, N. (2000). Bilingual education policy and practice in the Andes: Ideological paradox and intercultural possibility. Anthropology \& Education Quarterly 31(2), 173-201.

Jiménez, R. T. (2004). Reconceptualizing the literacy learning of Latino students. In D. Strickland \& D. Alvermann (Eds.), Bridging the literacy achievement gap, Grades 4-12 (pp. 17-29). New York: Teachers College Press.

Joseph, M. (1999). Nomadic identities: The performance of citizenship. Minneapolis: University of Minnesota Press.

Lamphere, L. (1992). Introduction: The shaping of diversity. In L. Lamphere (Ed.), Structuring diversity: Ethnographic perspectives on the new immigration (pp. 1-34). Chicago: University of Chicago Press.

Lee, C. (2004, Winter/Spring). Literacy in the academic disciplines. Voices in Urban Education, 3, $14-25$.

Levinson, B. (2001). We are all equal: Student culture and identity at a Mexican secondary school, 1988-1998. Durham, NC: Duke University Press.

Levinson, B. A., \& Holland, D. (1996). The cultural production of the educated person: An introduction. In B. A. Levinson, D. Foley, \& D. Holland, The cultural production of the educated person: Critical ethnographies of schooling and local practice (pp. 1-53). Albany: State University of New York Press. 
Limón, J. E. (1998). American encounters: Greater Mexico, the United States, and the erotics of culture. Boston: Beacon.

Lutton, L. (2006, February 8). Border crossings. Education Week, 27-29.

Luykx, A. (1999). The citizen factory: Schooling and cultural production in Bolivia. Albany: State University of New York Press.

Mahler, S. J. (1998). Theoretical and empirical contributions toward a research agenda for transnationalism. In M. P. Smith \& L. E. Guarnizo (Eds.), Transnationalism from below (pp. 64-100). New Brunswick, NJ: Transaction Publishers.

Massey, D. S., Alarcón, R., Durand, J., \& González, H. (1987). Return to Aztlán: The social process of international migration from western Mexico. Berkeley: University of California Press.

Moje, E. B., Ciechanowski, K. M., Kramer, K., Ellis, L., Carrillo, R., \& Collazo, T. (2004). Working toward third space in content area literacy: An examination of everyday funds of knowledge and discourse. Reading Research Quarterly, 39(1), 38-70.

Moll, L., Amanti, C., Neff, D., \& Gonzalez, N. (1992). Funds of knowledge for teaching: Using a qualitative approach to connect homes and classrooms. Theory Into Practice, 31(1), 132-141.

Moll, L. C. \& Gonzalez, N. (1997). Teachers as social scientists: Learning about culture from household research. In P. M. Hall (Ed.), Race, ethnicity, and multiculturalism: Policy and practice (pp. 89-114). New York: Garland.

Olneck, M. R. (1995). Immigrants and education. In J. A. Banks \& C. A. McGee Banks (Eds.), Handbook of research on multicultural education (pp. 310-327). New York: Macmillan.

Packer, M., \& Goicoechea, J. (2000). Sociocultural and constructivist theories of learning: Ontology, not just epistemology. Educational Psychologist, 35(4), 227-241.

Parker, W. C., Ninomiya, A., \& Cogan, J. (1999). Educating world citizens: Toward multi-national curriculum development. American Educational Research Journal, 36(2), 117-145.

Petron, M. A. (2003). I'm bien pocha: Transnational teachers of English in Mexico. Unpublished dissertation, University of Texas at Austin.

Piore, M. J. (1979). Birds of passage: Migrant labor and industrial societies. Cambridge: Cambridge University Press.

Plyler v. Doe, 457 U.S. 202 (1982).

Pugach, M. C. (1998). On the border of opportunity: Education, community, and language at the U.S.-Mexico line. Mahwah, NJ: Lawrence Erlbaum Associates, Inc.

Recio, M. (2002, January 25). Recession hits Hispanics hard, Study finds. Providence Journal, A3.

Reyes, X. A. (2000). Return migrant students: Yankee go home. In S. Nieto (Ed.), Puerto Rican students in U.S. schools (pp. 39-67). Mahwah, NJ: Lawrence Erlbaum Associates, Inc.

Rippberger, S., \& Staudt, K. (2002). Pledging allegiance: Learning nationalism at the El Paso/Juarez. Border. London: Routledge.

Robertson, T. (2002, February 2). An economic retreat: Worried about jobs some immigrants return to Mexico. Boston Globe, A1, A4.

Rosaldo, R. (1989). Culture and truth. Boston: Beacon.

Serrano, I. (1998, August). A comparative study of classroom coping behavior in the English and Spanish classes of return migrant and non-migrant Puerto Rican students. Educación, 93-124.

Sizer, T. R., \& Sizer, N. F. (1999). The students are watching: Schools and the moral contract. Boston: Beacon.

Smith, M. P. (1994). Can you imagine? Transnational migration and the globalization of grassroots politics. Social Text, 39, 15-33.

Smith, M. P., \& Guarnizo, L. E. (1998). The locations of transnationalism. In M. P. Smith \& L. E. Guarnizo (Eds.), Transnationalism from below (pp. 3-34). New Brunswick, NJ: Transaction Publishers.

Spener, D. (1988). Transitional bilingual education and the socialization of immigrants. Harvard Educational Review, 58(2), 133-153. 
Spindler, G. (1982). Self-appraisals: Concerns and strategies. In G. Spindler (Ed.), Doing the ethnography of schooling: Educational anthropology in action (pp. 14-18). New York: Holt, Rinehart and Winston.

Stark, O. (1991). The migration of labor. Cambridge: Basil Blackwell.

Suárez-Orozco, C., \& Suárez-Orozco, M. (2001). Children of immigration. Cambridge, MA: Harvard University Press.

Tienda, M. (1989). Looking to the 1990s: Mexican immigration in sociological perspective. In W. A. Cornelius \& J. A. Bustamante (Eds.), Mexican migration to the United States: Origins, consequences, and policy options (pp. 109-147). San Diego, CA: Center for U.S./Mexican Studies, University of California.

Trueba, E. T. (1999). The education of Mexican immigrant children. In M. Suárez-Orozco (Ed.), Crossings: Mexican immigration in interdisciplinary perspective (pp. 253-275). Cambridge, MA: Harvard University, David Rockefeller Center for Latin American Studies.

Tyack, D. (1974). The one best system: A history of American urban education. Cambridge, MA: Harvard University Press.

Valdés, G. (1996). Con respeto. New York: Teachers College Press.

Valdés, G. (2001). Learning and not learning English. New York: Teachers College Press.

Wong Fillmore, L., \& Meyer, L. M. (1992). The curriculum and linguistic minorities. In P. W. Jackson (Ed.), The handbook of research on curriculum (pp. 626-658). New York: Macmillan.

Zúñiga, V. (2000). Migrantes internationales de México a Estados Unidos: Hacia la creación de políticas educativas binacionales. In R. Tuirán (Ed.), Migración México-Estados Unidos, Opciones de política (pp. 299-334). México: Consejo Nacional de Población-Secretaría de Relaciones Exteriores.

Zúñiga, V., \& Hernández-León, R. (Eds.). (2005). New destinations: Mexican immigration in the United States. New York: Russell Sage. 